Kovrov 0.,
Kolesnyk V.

\title{
DEVELOPMENT OF THE LANDSLIDE HAZARD CONTROL SYSTEM OF NATURAL AND MAN-MADE SLOPES
}

Об’єктом дослідження є управління зсувонебезпечністю природних схилів і техногенних укосів, як чинника екологічної безпеки та стійкості геомеханічних систем. Одними із проблемних аспектів у вирішенні иієї наукової проблеми є відсутність комплексного підходу при вивченні зсувів та недостатній обсяг лабораторних досліджень фізико-механічних властивостей м'яких суглинистих порід та грунтів. Для вірогідного прогнозу та управління зсувонебезпечністю необхідно поєднання аналітичних та лабораторних досліджень, методів чисельного моделювання стійкості схилів, що і було використано у проведеному дослідженні.

Обгрунтована 5-рівнева очіночна шкала зсувонебезпечності природних схилів і техногенних укосів для управління їх стійкістю. Шкала зсувонебезпечності дозволяє достовірно прогнозувати геомеханічний стан масиву гірських порід залежно від значень коефіцієнта запасу стійкості схилу в мінливих геокліматичних умовах та обгрунтовувати ефективні заходи інженерного захисту від зсувів. Запропонована класифікація зсувонебезпечності природних схилів та укосів за значенням коефіцієнтів запасу стійкості. Вона може використовуватись як для оцінки стійкості техногенних укосів суцільних та насипних порід, так $i$ для прогнозу екологічної небезпеки від зсувів внаслідок надзвичайних ситуацій.

Розроблена структурно-логічна схема управління зсувонебезпечністю на регіональному та локальному рівнях базується на сучасних методологічних підходах стосовно оцінки та прогнозу стійкості природних схилів і штучних укосів. Завдяки застосуванню комплексного підходу для оцінки стійкості та зсувонебезпечності схилів та укосів забезпечується можливість науково обгрунтованого моніторингу цих геооб'єктів.

Використання запропонованої системи управління зсувонебезпечністю дозволяє обгрунтовувати стійкі параметри геотехнічних об'єктів (техногенних укосів) при відкритій розробці корисних копалин з урахуванням геометричних параметрів, фізико-механічних характеристик, обводнення масиву порід та зовнішніх навантажень. Для природних схилових ландиафтів використання комплексного підходу є ефективним інструментом визначення умов зсувів.

Ключові слова: зсувонебезпечність природних схилів і техногенних укосів, коефічієнт запасу стійкості, система прогнозу і управління.

\section{Introduction}

Landslide hazard is an important component of the ecological safety of territories, including man-made and geomechanics of soils and soft rocks, both at the regional and local levels.

Natural and man-made slopes are almost always present in different areas, are sources of potential environmental or technological hazards, emergency or catastrophe. Under the influence of gravity and man-made external loads, the slopes are destroyed, causing significant environmental, economic and social losses. Taking into account global and regional climate change trends, the intensity of landslide hazard with corresponding ecological consequences in natural slope landscapes and in the technical system with complex or artificially created relief is growing.

The main factors influencing the stability of natural and man-made slopes are the climatic and hydrogeological indicators of the territory, in particular, the amount of precipitation and water saturation of mainly soft loamy rocks, as well as their geomechanical properties. Economic activity, industrial and civil development, seismic effects often act as triggering factors for landslides. An analysis of the trends in the spread of landslides in the world over the past and current century indicates a tendency of growth in their number, scale, and death due to disastrous consequences. Each year, approximately 9,000 people become victims of landslides in the world [1]. To date, about 23 thousand landslides have been recorded on the territory of Ukraine and their number is constantly growing due to over-wetting of the upper layers of unstable loamy, including loess soils [2]. Favorable conditions for the activation of landslides have developed within the built-up urban areas of Vinnytsia, Dnipropetrovsk, Donetsk, Zakarpattia, Ivano-Frankivsk, Kyiv, Luhansk, Odesa, Kharkiv, Chernivtsi and other regions of Ukraine.

Landslides of artificial or man-made origin are observed in the slopes of the ledges and sides of quarries for the extraction of mineral resources as a result of technological operations of open development, during the construction and operation of geotechnical structures.

At the same time, the existing methods for landslide hazard evaluation of natural and man-made slopes do not provide reliable forecasting of the moment of occurrence and scale of an emergency situation and the introduction of preventive measures.

Based on the foregoing, the development of a landslide hazard control system for the natural and man-made slopes remains an urgent scientific task, the solution to which this work is devoted. 


\section{The object of research and its technological audit}

The object of research is the landslide hazard control system of natural and man-made slopes, as a factor in environmental safety and stability of geomechanical systems.

The slope (slopes) is a geomorphological object (geoobject) that was formed naturally or artificially and has certain geometrical (height and angle of inclination) structural (heterogeneity, layering) and physical and mechanical properties (adhesion and angle of internal friction). The natural slope is any element of the ravine network. An example of man-made slope is the side of the quarries, rock heaps and embankments formed in the technological processes of open-cast mining, in civil engineering, and the like. A number of natural (climate, geomerphology, moisture saturation) and man-made (static and dynamic loads, seismic effects) factors influence these geo objects. These influences violate the stability of slopes and slopes and increase the landslide hazard level.

One of the most problematic places is the lack of an integrated approach in the study of landslides and insufficient laboratory studies of the physico-mechanical properties of soft loamy rocks and soils.

Therefore, the evaluation and forecasting of the sustainability of natural and man-made slopes in changing geoclimatic conditions is a key element managing their landslide hazard control to ensure environmental and technological safety.

\section{The aim and objectives of research}

The aim of research is increasing the reliability of forecasting of the landslide hazard levels of natural and man-made slopes and the effectiveness of controlling their sustainability to ensure the ecological and man-made safety of the regions and local territories.

To achieve this aim, the following research objectives are solved:

1. To substantiate the estimated landslide hazard scale of natural and man-made slopes for the further control of their stability.

2. To develop a landslide hazard control system of natural and man-made slopes with a heterogeneous structure in varying geoclimatic conditions in a regional and local context.

\section{Research of existing solutions of the problem}

Recently, the development of landslides in the regions of Ukraine has had a disastrous rate, which is associated with significant economic and social losses. Therefore, modern studies of landslide phenomena in natural landscapes and geotechnical systems are aimed at improving the reliability of evaluating the stability of slopes and developing effective measures for monitoring and control of landslide hazard. So, the substantiation and implementation of effective landslide hazard control systems for the natural and man-made slopes is an important applied direction of scientific research in the field of environmental and technological safety of the regions and the state as a whole.

A number of researches of famous scientists are devoted to modern problems of slope stability and geodynamics of landslides in natural ecosystems.
Thus, in [3], the results of landslide studies in a regional context are highlighted, taking into account the geomorphological and climatic features of the territories.

The work [4] presents the most famous classifications by definition of stable parameters of slopes in open pits. But for natural slopes, it is unacceptable due to the lack of an ecological component of the landslide hazard level.

In [5], modern methods and approaches are presented that consider the slopes of open pit mines as complex geotechnical structures that have natural geological and geomechanical properties. However, the presented methodology does not take into account the hydrogeological characteristics of the rock massif, significantly affects their strength.

In $[6,7]$, the stability of slopes is estimated using probabilistic approaches. The disadvantage of these methods is the limited application of the known criteria for the destruction of rocks, which raises doubts about the reliability of the results.

To control the risks of landslide hazard slopes in large quarries, ground-based radars are used; it provides high accuracy in studying the stability of slopes in real time [8,9]. However, the use of geodetic radar does not provide a complete picture of the deformation processes occurring in the rock mass at the moment of collapse.

For a complete evaluation of the stability of slopes, it is necessary to take into account the presence of cracks or other discontinuities of the medium in the array [10], as well as the groundwater level and moisture saturation of the rock massif, which significantly affects the stability factor [11].

This factor is key and is associated with climate change, precipitation [12] and other natural factors [13], which significantly affect the intensification of natural landslides.

Thus, the results of the analysis allow to conclude that the subject of the forecast and control of such a scenario is diverse and requires a systematic approach.

\section{Methods of research}

The following scientific methods are used:

- method for analyzing information sources and world experience in formulating a scientific goal and research objectives;

- classification methods for evaluating the stability of slopes and slopes;

- methods of environmental evaluation and monitoring for the forecasting and landslide hazard control in natural geosystems and man-made objects.

\section{Research results}

6.1. Substantiation of the step scale of the landslide hazard level and the corresponding classification of natural slopes. Landslide hazard is a factor of environmental and technological risk. The use of appropriate levels and gradations of the stability of natural and man-made slopes is a key element in the evaluation and forecasting of their landslide hazard. Regarding geotechnical objects of openpit mining of minerals, the known scales of the values of the safety factors for slopes and pit walls, as well as dump arrays are used [14]. To evaluate the stability of natural slopes, such a gradation of the landslide hazard levels is absent. Therefore, taking into account the statistics of activation and spread of landslides in the world and Ukraine, there is a need to substantiate a certain scale 
of landslide hazard levels in order to evaluate the risk of exogenous geological processes in natural geosystems.

As is known, the criterion for evaluating the state of natural and man-made slopes is stability factor $(S F)$, which represents the ratio of retaining $F_{r}$ and landslide $F_{l}$ forces in the slope along the sliding surface, that is:

$$
S F=F_{r} / F_{l}
$$

Three states of the slope section of the rock mass are possible: at $S F>1.0$, the slope is steady, $S F=1.0$ corresponds to the limiting state at the moment of initiation of a slope collapse or slope, which goes into a state of collapse (shift) at $S F<1.0$

The $S F$ value for the slopes of soft rocks can vary within wide limits, but for the practical application of this indicator, it is most expedient to analyze the calculated $S F$ values in the interval $[1.0 ; 2.0]$. Under the conditions of the complex effect of natural and man-made stress factors in the slope grow, which leads to changes in the stress-strain state of the slope array. These changes are characterized by certain objective transformations in the array that can be monitored or observed. It is precisely this that made it possible to establish the gradation of the state of the slope and propose a five-step scale for the landslide hazard levels (Fig. 1). The appropriate classification proposed by the authors for the landslide hazard of natural slopes, which is based on the SF value, is given in Table 1.

As a result of numerical simulation, it is found that in homogeneous slopes without attenuation surfaces, significant deformations are practically absent with a $S F \geq 1.5[14,15]$. This state of the soft rock massif is objectively characterized as the most stable, therefore, the landslide hazard level is «low», which makes it possible to assign this position to the I class of hazard level according to the proposed scale. The growth of stresses on the slope $(1.2<S F \leq 1.5)$ leads to the appearance of certain deformations, the landslide hazard level is «moderate» and is referred to class II of landslide hazard. In conditions of further reduction of the strength properties of the soil or rock mass, as a result of loads or changes in moisture saturation in the slope, stresses increase and separate deformation zones appear. This allows to consider the landslide hazard level as «average» and refer this position to class III on the landslide hazard scale. Further development of geomechanical deformations $(1.0<S F \leq 1.1)$ leads to chips and cracks in the slope, and this makes it possible to consider the landslide hazard level as «increased» and to distinguish its IV level. The condition of the slope collapse, in which the $S F=1.0$, it is proposed to refer to the maximum landslide hazard level - «critical» and in accordance to the class V.

The analysis of the stability levels proposed in [4] relative to the working slopes of quarries and dumps from soft loamy rocks indicates that the lowest SF values within 1.1...1.2. However, it should be borne in mind that, over time, such slopes have a tendency to the destruction, spreading and development of various landslide phenomena under the influence of external factors, mainly precipitation and overwatering. In addition, the determination of the physicomechanical characteristics of rocks in the laboratory has certain disadvantages associated with the variation of the values of adhesion and angle of internal friction in real rocks of slopes, even within the same engineeringgeological element. Variations of the strength properties and statistical heterogeneity of soils and loamy rocks can weighfully influence the results of laboratory tests, and, as a result, the $S F$ value calculation of the slope.

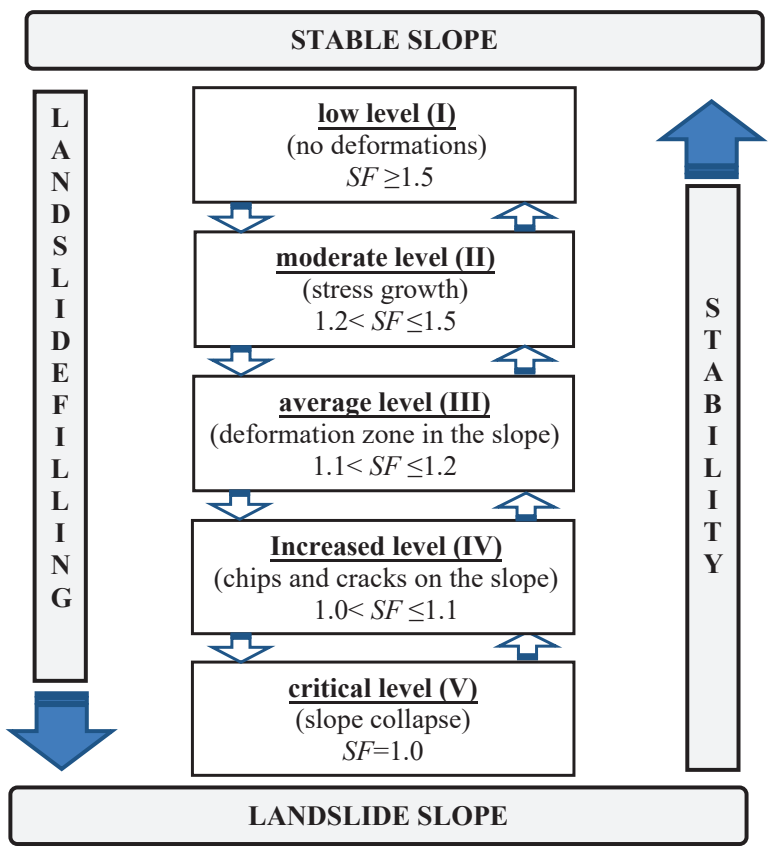

Fig. 1. Landslide hazard and the stability of natural slopes

Table 1

Landslide hazard levels of natural slopes according to the SF value

\begin{tabular}{|c|c|c|c|c|}
\hline $\begin{array}{l}\text { Landslide } \\
\text { hazard } \\
\text { levels }\end{array}$ & $\begin{array}{c}\text { SF value, } \\
\text { dimension- } \\
\text { less }\end{array}$ & $\begin{array}{c}\text { Landslide } \\
\text { hazard } \\
\text { class }\end{array}$ & $\begin{array}{l}\text { Hazard } \\
\text { type }\end{array}$ & Note \\
\hline Low & $S F \geq 1.5$ & I & Man-made & \multirow{2}{*}{$\begin{array}{l}\text { Used for man-made } \\
\text { slopes of solid and } \\
\text { bulk rocks }\end{array}$} \\
\hline Moderate & $1.2<5 F \leq 1.5$ & II & Man-made & \\
\hline Average & $1.1<5 F \leq 1.2$ & III & Ecological & \multirow{3}{*}{$\begin{array}{l}\text { Characterizes the en- } \\
\text { vironmental hazard } \\
\text { caused by landslides } \\
\text { due to an emergency }\end{array}$} \\
\hline Increased & $1.0<5 F \leq 1.1$ & IV & Ecological & \\
\hline Critical & $S F=1.0$ & V & Ecological & \\
\hline
\end{tabular}

Despite this, the five-step landslide hazard scale is proposed for the avoidance of natural and man-made slopes, depending on the $S F$ values in changing geoclimatic conditions. This allows a fairly reliable forecasting of the geomechanical state of the rock mass and the development of effective engineering measures for protection against landslides.

6.2. Building the structure of the landslide hazard control system of the natural and man-made slopes. The results of the studies carried out in the work are systematized in the form of a structural-logical scheme based on modern methodological approaches regarding the forecasting of the stability of natural and man-made slopes and control of their landslide hazard levels. This makes it possible to build the landslide hazard control structure for slopes, which shown in Fig. 2.

The proposed logically constructed and tested in practice structural control scheme for the landslide hazard unites three modules: evaluation, forecast and control. Each of these modules is based on a specific set of methodological approaches, it allows to solve scientific problems regarding the landslide hazard forecasting of the slopes. 


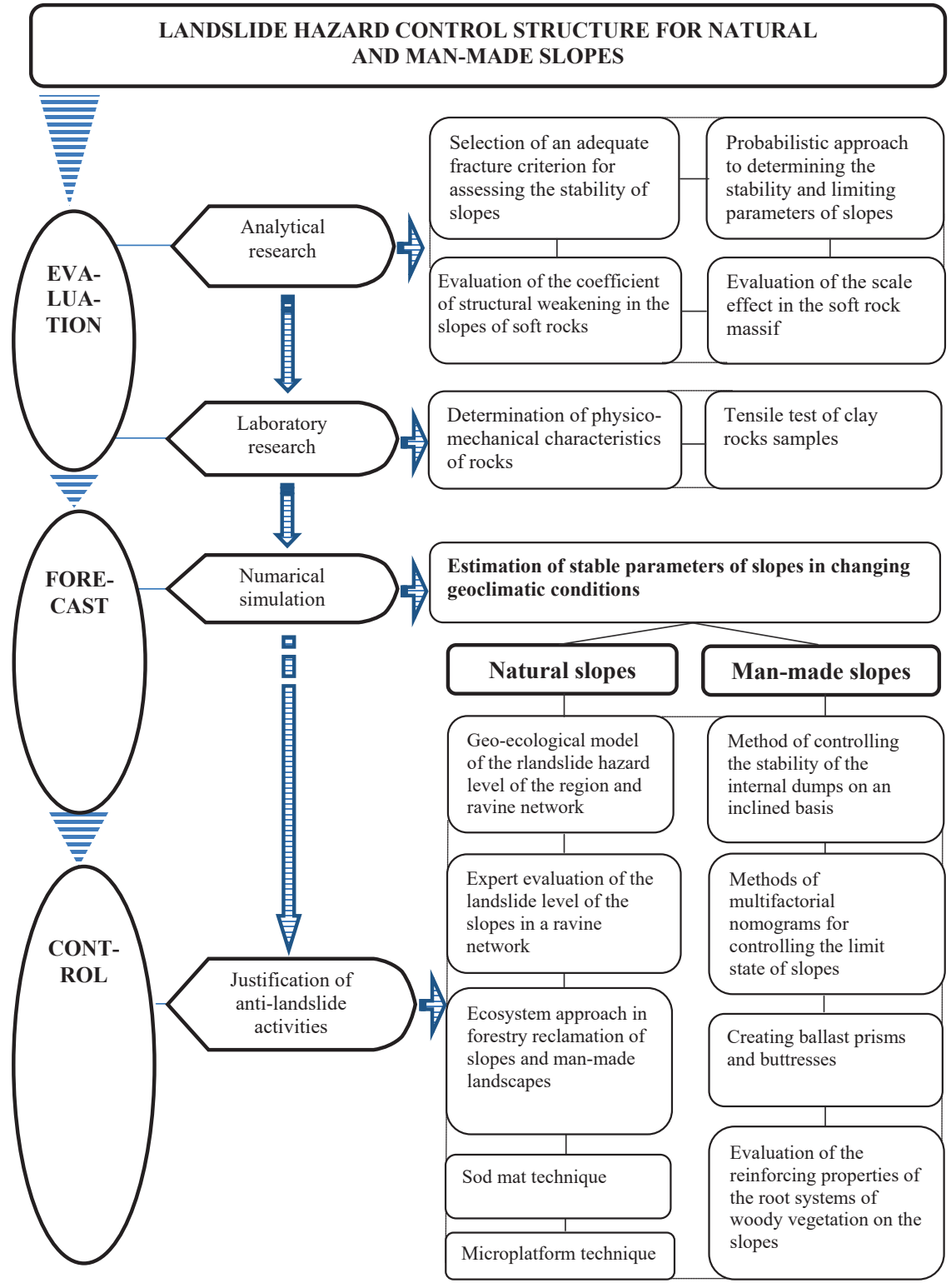

Fig. 2. The control structure of the landslide hazard of the slopes of the rock mass and external loads. For natural slope landscapes using an integrated approach is an effective tool for determining the conditions of landslides.

Threats. Despite the obtained quite reliable results of the evaluation and forecasting of landslide hazard, the responsible government agencies refer to such research and the introduction of anti-landslide measures with certain skepticism due to the lack of targeted funds and the uncertainty of the time frame for the occurrence of a landslide. As a rule, the financing of anti-landslide measures takes place at the stage of eliminating the consequences of an emergency or catastrophe.

\section{Conclusions}

1. It is shown that the landslide hazard level of the natural and manmade slopes is determined by changes in their stability factor (SF), which is caused by the influence of geometric, geomechanical and geoclimatic factors. This makes it possible to substantiate the five-step landslide hazard scale of the natural slopes of the classification of levels, classes and types of danger, based on the SF value.

2. A logical structured scheme for a landslide hazard control at the regional and local levels is proposed and logically built, which combines three modules: evaluation, forecast and control. Each of these modules is based on a specific set of methodological approaches, it allows to solve scientific problems regarding the forecasting of the landslide hazard of the slopes.

\section{SWOT analysis of research results}

Strengths. Compared with similar approaches regarding the stability of natural man-made slopes, a comprehensive methodology is proposed based on the results of analytical and laboratory studies, numerical modeling, and the use of innovative landfill measures. This allows to reliably controlling the landslide hazard.

Weaknesses. The weaknesses of the proposed landslide hazard control system include the difficulties in the laboratory determination of the strength properties of soils and loamy rocks. As well as their statistical heterogeneity, in varying degrees, affect the results of calculating reliable $S F$ values of the slope. Therefore, for reliable engineering calculation of slope stability, it is advisable to use probabilistic-statistical approaches.

Opportunities. The use of the proposed landslide hazard control system allows justifying the stable parameters of geotechnical objects (man-made slopes) during the open development of minerals with due regard for geometrical parameters, physical and mechanical characteristics, flooding

\section{References}

1. Petley D. Global patterns of loss of life from landslides Geology. 2012. Vol. 40, Issue 10. P. 927-930. doi: http://doi.org/ $10.1130 / \mathrm{g} 33217.1$

2. Natsionalna dopovid pro stan navkolyshnoho pryrodnoho seredovyshcha v Ukraini u 2014 rotsi / ed. by Bondar O. I. et. al. Kyiv: Hrin D. S., 2016. 350 p.

3. Inzhenernaya geodinamika Ukrainy i Moldovy (opolznevye geosistemy). Vol. 2 / ed. by Rud'ko G. I., Osiyuk V. A. Chernovtsy, 2012. 744 p.

4. Gal'perin A. M. Geomekhanika otkrytykh gornykh rabot. Moscow, 2003. 473 p.

5. Leurisson J.-A. Slope Design and Implementation in Open Pit Mines: Geological and Geomechanical Approach // Procedia Engineering. 2012. Vol. 46. P. 27-38. doi: http://doi.org/10.1016/ j.proeng.2012.09.442

6. Hamedifar H. Role of Probabilistic Methods in Sustainable Geotechnical Slope Stability Analysis // Procedia Earth and Planetary Science. 2014. Vol. 9. P. 132-142. doi: http://doi.org/10.1016/ j.proeps.2014.06.009

7. Luo N., Bathurst R. J., Javankhoshdel S. Probabilistic stability analysis of simple reinforced slopes by finite element method // 
Computers and Geotechnics. 2016. Vol. 77. P. 45-55. doi: http:// doi.org/10.1016/j.compgeo.2016.04.001

8. Development and application of a pseudo-3D pit slope displacement map derived from ground-based radar / Severin J. et. al. // Engineering Geology. 2014. Vol. 181. P. 202-211. doi: http://doi.org/10.1016/j.enggeo.2014.07.016

9. Osasan K. S., Stacey T. R. Automatic prediction of time to failure of open pit mine slopes based on radar monitoring and inverse velocity method // International Journal of Mining Science and Technology. 2014. Vol. 24, Issue 2. P. 275-280. doi: http://doi.org/10.1016/j.ijmst.2014.01.021

10. Stability analysis of seismic slopes with cracks / Zhao L.-H. et. al. // Computers and Geotechnics. 2016. Vol. 77. P. 77-90. doi: http://doi.org/10.1016/j.compgeo.2016.04.007

11. Stability analysis of slopes with ground water during earthquakes / Lu L. et. al. // Engineering Geology. 2015. Vol. 193. P. 288-296. doi: http://dx.doi.org/doi:10.1016/j.enggeo.2015.05.001

12. Gariano S. L., Guzzetti F. Landslides in a changing climate // Earth-Science Reviews. 2016. Vol. 162. P. 227-252. doi: http:// doi.org/10.1016/j.earscirev.2016.08.011

13. Sadovenko Y. A., Podvyhyna E. O., Zahrytsenko A. N. Dyfferentsyatsyia faktorov ustoichyvosty tekhnohenno nahruzhennikh lessovikh sklonov metodom matematycheskoho modelyrovanyia fyltratsyonnikh protsessov // Visnyk Odeskoho natsionalnoho universytetu. Seriia: Heohrafichni ta heolohichni nauky. 2013. Vol. 18, Issue 1. P. 147-154.

14. Influence of watering filled-up rock massif on geomechanical stability of the cyclic and progressive technology line / Kovrov O. et. al. // Mining of Mineral Deposits. 2016. Vol. 10, Issue 2. P. 55-63. doi: http://doi.org/10.15407/mining10.02.055

15. Sdvyzhkova E. A., Kovrov A. S., Kyryiak K. K. Heomekhanycheskaia otsenka ustoichyvosty opolznevoho sklona metodom konechnikh elementov // Naukovyi visnyk Natsionalnoho hirnychoho universytetu. 2014. Vol. 2. P. 86-92.

Kovrov Oleksandr, PhD, Associate Professor, Professor of the Department of Ecology and Environmental Protection Technologies, National Technical University «Dnipro Polytechnic», Ukraine, ORCID: http://orcid.org/0000-0003-3364-119X, e-mail: kovralex1@gmail.com

Kolesnyk Valerii, Doctor of Technical Sciences, Professor, Department of Ecology and Environmental Protection Technologies, National Technical University «Dnipro Polytechnic», Ukraine, ORCID: http:// orcid.org/0000-0003-2349-3576, e-mail: kolesnikve@yahoo.com

\section{Shuryberko M., Gomelya M., Gluchenko N., Chuprova K., Overchenko T.}

\section{DEVELOPMENT OF NEW COMPOSITIONS FOR REDUCING THE CORROSIVE AGGRESSIVENESS OF OIL-CONTAINING WATER}

Об'єктом дослідження є екологічно безпечні системи в нафтовидобувній та нафтопереробній промисловості. Всі стадії нафтокористування - видобування-переробка-використання - супроводжуються забрудненням довкілля. Суттєві забруднення виникають при видобуванні, транспортуванні та розливі нафти, скиді стічних вод, спалюванні та зберіганні нафтових відходів. Через наявність агресивних складових у складі нафтовмісних мінералізованих вод зростає швидкість корозї металевих конструкиій, що призводить до швидкого руйнування обладнання та трубопроводів. Тому одним з першочергових завдань $\epsilon$ захист металевих конструкцій від корозї у нафті та водонафтових емульсіях.

В роботі проведено оцінку агресивності водних розчинів різного нафто-мінерального складу при температурі $80^{\circ} \mathrm{C}$. Показано, що мінералізовані водні розчини є більш корозійно агресивними, аніж іх композицї з нафтою. Розроблено композиції для зниження корозійної агресивності нафтовмісних вод та визначено їх ефективність. Результати досліджень вказують, що інгібітор на основі алкілімідазоліну забезпечує високу ефективність захисту сталі від корозії при температурах від $30^{\circ} \mathrm{C}$ до $80^{\circ} \mathrm{C}$. Ступінь захисту при дозах

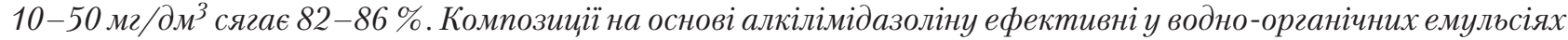
на основі мінералізованої води та петролейного ефіру лише за невисоких температур. При підвищених температурах, за рахунок високої летючості петролейного ефіру, формування захисної адсорбиійної плівки на поверхні сталі не відбувається.

В разі застосування інгібіторів корозї сталі на основі алкілімідазолінів можливо досягти високої ефективності захисту від руйнування як нафтопроводів, де, крім нафти, завжди присутні домішки мінералізованої води, так і водопроводів, де у високомінералізованих водах присутні домішки нафти. Перевагою алкілімідазолінів є те, що за рахунок гідрофільної та гідрофобної складових їхніх молекул вони добре розчиняються як у нафтопродуктах, так і у водному середовищі.

Ключові слова: нафтовмісні води, корозія металу, інгібітор корозї, швидкість корозії, алкілімідазолін.

\section{Introduction}

The aggressive impact of corrosive environments leads to increased corrosion of equipment, tanks, pipes and pipe fittings [1].
The corrosive aggressiveness of the water-oil emulsion varies depending on the composition of the aqueous phase, its ratio to the hydrocarbon phase, the composition and amount of gaseous substances. In the development of oil fields from the well to the surface enters the oil-gas-water 